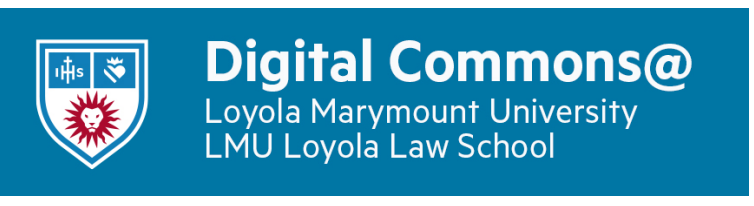

Journal of Catholic Education

\title{
Some Determinants of Classroom Psychosocial Environment in Australian Catholic High Schools: A Multilevel Analysis
}

Jeffrey P. Dorman

Follow this and additional works at: https://digitalcommons.Imu.edu/ce

\section{Recommended Citation}

Dorman, J. P. (2009). Some Determinants of Classroom Psychosocial Environment in Australian Catholic

High Schools: A Multilevel Analysis. Journal of Catholic Education, 13 (1). http://dx.doi.org/10.15365/

joce.1301022013

This Article is brought to you for free with open access by the School of Education at Digital Commons at Loyola Marymount University and Loyola Law School. It has been accepted for publication in Journal of Catholic Education by the journal's editorial board and has been published on the web by an authorized administrator of Digital Commons at Loyola Marymount University and Loyola Law School. For more information about Digital Commons, please contact digitalcommons@lmu.edu. To contact the editorial board of Journal of Catholic Education, please email JCE@nd.edu. 


\title{
ARTICLES
}

\section{Some Determinants of Classroom Psychosocial Environment in Australian Catholic High Schools: A Multilevel Analysis}

\author{
Jeffrey P. Dorman
}

Australian Catholic University, Queensland, Australia

This research investigated some determinants of classroom environment in Australian Catholic high schools. The Catholic School Classroom Environment Questionnaire (CSCEQ) was used to assess 7 dimensions of the classroom psychosocial environment: student affiliation, interactions, cooperation, task orientation, order and organization, individualization, and teacher control. The sample consisted of 1,719 students from 80 classes in 20 Catholic coeducational and single-sex schools. Validation data attested to the sound structural properties of the CSCEQ. Because the data were nested (i.e., students within classes within schools), multilevel analyses were used to investigate the influence of student gender, grade, subject, and school type on students' perceptions of the classroom environment. Statistically significant associations between some of these grouping variables and some of the CSCEQ scales were evident, with student gender and grade the main explanatory variables. Variance in order and organization was not explained by any of the four hypothesized grouping variables.

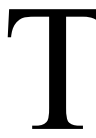

The study of classroom environments has developed into an important field of educational research during the past 35 years. Vivid descriptions and images of schools through powerful movies (e.g., To Sir With Love) and less powerful dramatizations (e.g., Beverly Hills 90210) all attest to the centrality of the environment to the defining character of schools and classrooms. The environment research reported in this paper concerns the classroom's psychosocial dimensions - those aspects that focus on human behavior in origin or outcome (Boy \& Pine, 1988). Accordingly, the concept of environment, as applied to educational settings, refers to the atmosphere, ambience, tone, or climate that pervades the particular setting. Questions like "Do boys and girls differ in their perceptions of the classroom environment?" and "Compared to Catholic coeducational schools, do Catholic single-sex schools have more positive classroom environments?" are fundamentally about classroom psychosocial environment. 
The strong methodological tradition of classroom environment research has been to conceptualize environments in terms of the perceptions of the milieu inhabitants (i.e., students and teachers) with context-specific instruments assessing particular dimensions of the learning environment. This field of research is particularly strong in the United States, Australia, and the Netherlands. The present paper reports research that investigated some determinants of classroom environment in Australian Catholic high schools. Before describing the research and its results and implications, the following two sections provide background information on Australian Catholic schools and the field of classroom environment research.

\section{Australian Catholic Schools}

Australia has a very substantial system of Catholic schools. It originated in the early 1800 s after the White settlement of Australia and developed through the arrival of religious orders in the late $1800 \mathrm{~s}$. The influence of the Irish people on Australian Catholicism and wider Australian society has been particularly strong. In 2007, there were 1,703 Catholic schools out of a total school population of 9,581. According to the Australian Bureau of Statistics (2008), $20.23 \%$ of the total Australian student population were enrolled in Catholic schools. Over $60 \%$ of private (i.e., non government) school students were in Catholic schools. It is also noteworthy that these Catholic schools receive substantial financial support directly from the Australian government. This support covers at least all staff salary costs with teachers receiving salary parity with their government school counterparts. Without this government support, the schools would close tomorrow.

The most fundamental point concerning Catholic secondary schools in Queensland is that all Catholic schools are agents of the Roman Catholic Church. It follows that they are empowered to provide an education for their students that is distinctive because of their Christ-centeredness. This is the starting philosophical point of any Catholic school and it means that Catholic schools should have an atmosphere that is consistent with a Christian view of the world. Over the past 2 to 3 decades, radical changes in the staffing composition of Australian Catholic schools have occurred with teaching religious orders replaced almost entirely by lay teachers. The issue of a Catholic school having a Catholic identity, taken for granted in the past, has assumed great importance to contemporary Catholic education.

It is reasonable to believe that Catholic schools cannot teach Catholic Christianity if the atmosphere enveloping the school is devoid of a Catholic ethos. Leavey's (1972) seminal Australian research in Catholic secondary girls' 
schools concluded that unless the students experience the procedures of their schools as reinforcing the content of the Christian message, then that message tends not to be accepted. There is almost universal agreement within Catholic education that Catholic schools must demonstrate their Christian commitment by having an appropriate learning environment. Bathersby (1992), the present Archbishop of Brisbane, asserted that the whole atmosphere of the school is one of shared faith where parents, teachers, and students come together in prayer and action to live the Gospel of Jesus. Much of the literature on the Catholic Church and Catholic schools suggests that Catholic schools possess distinctive learning environments. The original and continued official view of the Catholic Church is that, in some way, religious faith permeates the whole of the curriculum. This was implicit in the original foundation of the Australian schools last century, and has been restated in official papers since the Second Vatican Council (Vatican II) of 1962-1965. Church documents spanning 130 years indicate that the Australian Catholic school was to have an atmosphere consistent with Church doctrines (Geoghegan, 1860), enlivened by the Gospel spirit (Abbott, 1966), and dependent not so much on subject matter or methodology as on the people who work there (Congregation for Catholic Education, 1977). From the Catholic viewpoint, education is holistic with the religious dimension penetrating the entire school. Conceptually, the notion of having parcels of religion interspersed with parcels of secular knowledge has been rejected strongly. In summary, the environment of a Catholic school is a critical indicator of the extent to which that school is fulfilling its mission.

\section{Classroom Environment Research}

To appreciate the concept of environment and its subtle effects, it is useful to consider a metaphor. In 1991, Walberg used Tolstoy's War and Peace to refer to the strength of an army as the product of its mass and that unknown $X$, or the spirit of the army. Observable inputs like guns are necessary, but not sufficient: The espirit de corps is critical in determining outcomes. So it is with human environments, like classrooms. Without a consideration of the psychosocial environment, the outcomes of schools cannot be optimized.

The use of the students' perceptions to assess classroom environment can be linked conceptually to Lewin's (1936) Field Theory and the Lewinian formula $\mathrm{B}=f(\mathrm{P}, \mathrm{E})$ (i.e., behavior is a function of person and the environment as it exists for that person). Murray (1938), Stern, Stein, and Bloom (1956), and Pace and Stern (1958) extended Lewin's work to develop a need-press theory in which persons are conceptualized in terms of their psychological needs and the environment in terms of its press. The environmental press satisfies 
or frustrates the need. Since the late 1960s, an overwhelming feature of classroom environment research has been the collection and analysis of student and teacher perceptual data.

Reviews of classroom environment research by Fraser (2007) and Dorman (2002) and edited books by Khine and Fisher (2003) and Fisher and Khine (2006) have delineated at least 10 areas of classroom environment research, including associations between classroom environment and outcomes, evaluation of educational innovations, differences between students' and teachers' perceptions of classrooms, comparisons of actual and preferred environments, effect of determinants or antecedents on classroom environment antecedent variables (e.g., student gender, grade, subject, school type), transition from primary to secondary school, school psychology, student meta-cognition, teacher education, educational productivity research, and using environment instruments to facilitate changes in classroom life.

The research reported in this paper employed a high-inference measure of classroom environment that requires respondents to make judgments based on a sustained period of time in the classroom using specific constructs (e.g., cooperation). Studies that focus on the meaning of school and classroom events have tended to utilize high-inference measures as advocated strongly by Walberg (1976). That is, students should be asked to make summary molar judgments about their classrooms rather than piecemeal reporting on a myriad of molecular events.

Some areas of contemporary classroom environment research include monitoring interpersonal behavior and student outcomes in vocational classes (Henderson \& Fisher, 2008), investigating parent and student perceptions of classroom environments (Allen \& Fraser, 2007), studying the classroom climate and students' goal structures in high school biology classes in Kenya (Mucherah, 2008), and investigating the effect of extended instructional time on learning environment, achievement, and attitudes in middle school algebra classes (Azimioara \& Fraser, 2007). Recent edited volumes have documented the growth in learning environment research over the past decade (see Fisher \& Khine, 2006; Goh \& Khine, 2002; Khine \& Fisher, 2003). Classroom environment literature has significant overlap with aspects of the student engagement literature (see Fredricks, Blumenfeld, \& Paris, 2004). Establishing cohesive classroom environments that have high-quality relationships and active student participation are critical to student academic engagement.

One important consideration of classroom environment theory since the early 1970s has been Moos's (1979) conceptual framework for human environments that categorizes environment as having relationship, personal growth, system maintenance, and system change dimensions. Whereas 
relationship dimensions are concerned with the nature and intensity of personal relationships, personal growth dimensions focus on opportunities for personal development and self-enhancement. System maintenance and system change dimensions assess the extent to which the environment is orderly, clear in expectations, maintains control, and is responsive to change.

The present study focuses on the determinants of classroom environments in Catholic high schools, a line of research that has not been as prolific in recent years as the study of associations between classroom environment and outcomes. Previous research on the determinants of classroom environments have involved grouping variables like grade, school type, school location, student gender, and teacher gender. Other studies have employed continuous variables as predictors of classroom environment (e.g., class size, school-level environment, teacher personality, teacher competency, and student motivation). The assessment of classroom environment as part of formal curriculum evaluations fall into this line of research. In fact, the foundational classroom environment research of Walberg in the 1960s was part of the evaluation of Harvard Project Physics (see Welch \&Walberg, 1972). A review of all of these studies is outside the scope of this paper, with details on these studies and others provided in various reviews (e.g., Fraser, 1986, 2007).

The study of the determinants of classroom environment is important because it provides researchers, administrators, and practitioners with evidence on variables that influence the classroom environment. It allows teachers to fine-tune classrooms so that the environment matches the particular contextual attributes of the classes they are teaching. As the present study investigated four determinants of classroom environments in Catholic high schools (viz., student gender, grade, subject, and school type), the following section briefly reviews previous research on these variables.

Previous research has shown that student gender is a significant predictor of classroom environment perceptions. A consistent pattern of girls perceiving the classroom environment more positively than boys is evident (e.g., Fraser \& Chionh, 2000; Lawrenz, 1987). Two relatively recent studies on the effect of gender confirm this view. Fisher, den Brok, and Rickards's (2006) study in Australian high schools revealed that, compared to girls, boys perceived teachers to be less cooperative. In India, Koul and Fisher (2006) studied the effect of gender on classroom environment. They employed the Questionnaire on Teacher Interaction (Wubbels \& Levy, 1993) and the What Is Happening In this Class survey (Fraser \& Chionh, 2000). Female students reported significantly higher levels of leadership, helping/friendly, understanding, student cohesiveness, task orientation, cooperation, and equity, but significantly lower levels of uncertainty, dissatisfaction, and admonishing. 
Given the description of these scales, it is clear that females perceive the classroom environment more positively than males.

The effect of grade has also been researched with varying results. Randhawa and Michayluk (1975) showed that as grade increased, students perceived the classroom environment less positively. In one of the few relatively recent studies on the effect of grade on classroom environment, Cheng (1999) reported the use of Moos and Trickett's (1987) Classroom Environment Scale with junior and senior grades in Hong Kong high schools. Grade level differences were more pronounced for "superior performance schools" compared to "inferior performance schools." Senior grades perceived greater teacher support, task orientation, and order and organization, but reduced levels of affiliation, rule clarity, and teacher control.

Very little research has been conducted recently in Australia investigating the different environments in various secondary school subjects. Previous research in America has shown that classroom environment varies with subject matter (Anderson, 1971; Steele, Walberg, \& House, 1974; Welch, 1979). Some of these differences have been shown to occur between mathematics and science oriented subjects and humanities subjects. Steele, Walberg, and House (1974) found that secondary school mathematics classes emphasized analysis, memory, testing, and grades to the detriment of discussion. By contrast, language classes emphasized synthesis, evaluation, and participation. Anderson (1971) found that high school subjects differed on friction, favoritism, formality, disorganization, apathy, and goal direction. Lawrenz (1976) used the Learning Environment Inventory (Fraser, Anderson, \& Walberg, 1982) to differentiate between the environments of biology, chemistry, and physics classes. In the only recent study on the effect of subject on classroom environment, Fisher, den Brok, and Rickards (2006) compared teacher interactions in science classes with other classes. Results were mixed with students reporting less teacher cooperation in science classes, compared to other classes but no differences in other dimensions like the degree of domination shown by the teacher. While Levy, den Brok, Wubbels, and Brekelmans (2003) showed that mathematics and science teachers displayed less understanding and leadership than teachers of other subject areas, other studies found them to be more cooperative and dominant (see Wubbels \& Levy, 1993).

Trickett, Trickett, Castro, and Schaffner's (1982) study of single-sex and coeducational private schools in the United States reported significant differences between single-sex and coeducational school classrooms on 6 of the 9 scales of the Classroom Environment Scale (viz., involvement, affiliation, task orientation, competition, order and organization, and teacher 
control). For all of these scales, the single-sex schools scored higher than the coeducational schools. Schneider and Coutts's (1982) study of the environment in Catholic schools in Ontario, Canada is important because Catholic schools in Ontario have similar characteristics to Australian Catholic schools. They are government funded up to Grade 10 in a similar way to Australian Catholic schools and they educate a significant proportion of Ontario's student population. Schneider and Coutts found coeducational schools to have greater student affiliation and pleasure but less emphasis on control and discipline than single-sex schools. The study concluded that the coeducational school students provided a considerably more favorable description of the social psychological environments of their schools than did the single-sex school students.

\section{The Present Investigation}

\section{Aims}

The aims of this research were to:

- validate the Catholic School Classroom Environment Questionnaire (CSCEQ); and

- use multilevel analysis to investigate the influence of student gender, grade, subject, and school type on students' perceptions of the classroom environment as assessed by scales of the CSCEQ.

\section{Sample}

As noted earlier in this paper, Australia has a very substantial population of Catholic schools. These schools are located throughout the country from the major cities (e.g., Sydney) to quite remote locations. Currently, there are 86 Catholic high schools in Queensland and 51 of these are located in Brisbane. The sample employed in this study consisted of 1,719 students from 20 Queensland Catholic high schools. Multistage cluster sampling was used to draw the sample of schools, then classes, and then students. Table 1 describes the sample. Of the sample, 861 were male and 858 were female. As shown in Table 1, students were grouped according to subject (religious education or science), grade (9 or 12), and school type (coeducational, single-sex girls, or single-sex boys). Religion and science classes were chosen for this study as they represent two elements of the formal curriculum that are often considered divergent. 
Table 1

Description of Student Sample

\begin{tabular}{|c|c|c|c|c|c|}
\hline \multirow{2}{*}{ Subject } & & \multicolumn{3}{|c|}{ School Type } & \multirow{2}{*}{ Total } \\
\hline & & Coeducation & Girls' & Boys' & \\
\hline \multirow{2}{*}{$\begin{array}{l}\text { Religious } \\
\text { Education }\end{array}$} & Grade 9 & $228(10)$ & $108(5)$ & $108(5)$ & $444(20)$ \\
\hline & Grade 12 & $237(10)$ & $107(5)$ & $105(5)$ & $449(20)$ \\
\hline \multirow{2}{*}{ Science } & Grade 9 & $205(10)$ & $122(5)$ & $120(5)$ & $447(20)$ \\
\hline & Grade 12 & $186(10)$ & $98(5)$ & $95(5)$ & $379(20)$ \\
\hline Total & & $856(40)$ & $435(20)$ & $428(20)$ & $1,719(80)$ \\
\hline
\end{tabular}

Note. The number of classes is in parentheses.

\section{Instrumentation}

Assessment of classroom environment. The Catholic School Classroom Environment Questionnaire (CSCEQ) consists of 66 items assigned to 7 underlying scales that attempt to assess what it is really like in classrooms from the students' perspective. It has been shown to provide a valid assessment of classroom environment in Australian Catholic schools. Table 2 shows descriptions and the number of items for each CSCEQ scale.

Each scale assesses a dimension of the classroom environment deemed important to Catholic schools. For example, the student affiliation assesses the extent to which students know, help, and are friendly toward one another. This is an important characteristic of authentic Catholic school environments. Similarly, the interactions scale is concerned with the quality of teacher-student interactions and the personal welfare and social growth of students. Evidence in support of these two relationship scales is found in Scripture, and in Catholic Church and education documents. In the Gospel of Mark, we hear: "No; anyone who wants to become great among you must be slave to all. For the Son of Man himself did not come to be served but to serve, and to give his life as a ransom for many" (Mark 10: 43-45). The Congregation for Catholic Education asserted that "faith is principally assimilated through contact with people whose daily life bear witness to it" (1977, pp. 41-42) and urged "a determination to collaborate in achieving common educational goals" (1988, p. 33) and the strengthening of partnerships between school and family. In such communities, teachers, directors, administrative and auxiliary staff, and students are active rather than passive agents. Collaboration within this community brings to life the communitarian dimensions of the human 
Table 2

Descriptive Information for the CSCEQ

\begin{tabular}{|c|c|c|c|c|c|c|c|c|c|}
\hline CSCEQ Scale & Scale Description & Items & $\begin{array}{c}\text { Coeff't } \\
\alpha\end{array}$ & $M$ & $S D$ & sem & $\min$ & $\max$ & $\begin{array}{c}\mathrm{K}-\mathrm{S} \\
Z\end{array}$ \\
\hline $\begin{array}{l}\text { Student } \\
\text { Affiliation }\end{array}$ & $\begin{array}{l}\text { Extent to which students know, } \\
\text { help, and are friendly toward } \\
\text { one another. }\end{array}$ & 9 & .69 & 3.51 & 0.53 & 0.30 & 1.44 & 5.00 & $2.83^{*}$ \\
\hline Interactions & $\begin{array}{l}\text { Extent to which teacher-student } \\
\text { interactions emphasize a } \\
\text { concern for the personal welfare } \\
\text { and social growth of the student. }\end{array}$ & 10 & .90 & 3.71 & 0.74 & 0.23 & 1.00 & 5.00 & $3.98^{*}$ \\
\hline Cooperation & $\begin{array}{l}\text { Extent to which students } \\
\text { cooperate rather than compete } \\
\text { with one another. }\end{array}$ & 10 & .71 & 3.23 & 0.52 & 0.28 & 1.00 & 4.90 & $3.02^{*}$ \\
\hline Task Orientation & $\begin{array}{l}\text { Extent to which it is important to } \\
\text { complete activities planned and } \\
\text { to stay on the subject matter. }\end{array}$ & 9 & .76 & 3.17 & 0.65 & 0.32 & 1.22 & 5.00 & $2.27^{*}$ \\
\hline $\begin{array}{l}\text { Order \& } \\
\text { Organization }\end{array}$ & $\begin{array}{l}\text { Emphasis on students behaving } \\
\text { in an orderly, quiet, and polite } \\
\text { manner, and on the overall } \\
\text { organization of classroom } \\
\text { activities. }\end{array}$ & 10 & .84 & 2.71 & 0.69 & 0.28 & 1.00 & 4.90 & $1.98^{*}$ \\
\hline Individualization & $\begin{array}{l}\text { Extent to which students are } \\
\text { allowed to make decisions and } \\
\text { are treated differently according } \\
\text { to ability, interest, and rate of } \\
\text { working. }\end{array}$ & 9 & .54 & 2.66 & 0.47 & 0.32 & 1.00 & 4.56 & $2.52^{*}$ \\
\hline Teacher Control & $\begin{array}{l}\text { The number of rules, how } \\
\text { strictly rules are enforced, and } \\
\text { how severely infractions are } \\
\text { punished. }\end{array}$ & 9 & .75 & 3.47 & 0.61 & 0.31 & 1.22 & 5.00 & $2.69^{*}$ \\
\hline
\end{tabular}

Notes. Means and standard deviations were based on total scale score divided by the number of items in the scale. sem is the standard error of measurement ${ }^{*} p<.01$

person that are central to the Gospel of Jesus Christ. In the United States, Bryk and his colleagues (1984) noted the following explicit behaviors as integral to the Catholic school environment: Teachers know students by name, teachers have substantial contact with students both inside and outside the classroom, teachers value students, and teachers are patient and understanding. Overall, the distinctive environment of the Catholic school is reflected in the social interactions among students and faculty.

All CSCEQ items employ a 5-point Likert response format (viz., Strongly Disagree $=1$, Disagree $=2$, Neither $=3$, Agree $=4$, Strongly Agree $=5$ ) with item scores aggregated to form scale scores for each student respondent. Different versions of the CSCEQ have been used in previous research. For example, Dorman, McRobbie, and Foster (2002) used a personalized form of the CSCEQ to study associations between classroom environment in religion classes and their attitudes to Christianity. According to Moos's (1979) conceptual framework for human environments introduced earlier in this paper, student affiliation and interactions are relationship dimensions, cooperation 
and task orientation are personal growth dimensions, and order and organization, individualization, and teacher control are system maintenance and system change dimensions.

\section{Data Analysis}

Principal components factor analysis was used to substantiate the structure of the CSCEQ. The internal consistency reliability was computed using Cronbach's Coefficient $\alpha$ as a convenient index. This study of classroom environment involved 1,719 students in 80 classes in 20 Catholic schools. The data are hierarchical with students nested within classes, within schools (i.e., 3 levels). To investigate which grouping variables (viz., student gender, grade, subject, and school type) significantly explained variance in CSCEQ scale scores, multilevel analyses using MLwiN (Rasbash, Steele, Browne, \& Prosser, 2005) with the student as the first-level variable, class as the secondlevel variable, and school as the third-level variable were performed. These analyses consisted of a base variance components (i.e., null) model, which partitions the variance among the 3 levels (i.e., students, classes, and schools) for all CSCEQ scales followed by models that investigate the effect of student gender, grade, subject, and school type on the 7 CSCEQ scales.

Because the school type variable had three categories (viz., coeducational, girls, and boys) two dummy variables were created by MLwiN. These two variables were coded as coed $=0$, girls $=1$, and coed $=0$ and boys $=$ 1 , respectively. That is, coeducational schools were taken as the reference group. Accordingly, a total of five explanatory variables were entered into equations for the fitted models. To check for interaction effects involving student gender, interaction terms for student gender $\mathrm{x}$ level, student gender $\mathrm{x}$ subject, and student gender $\mathrm{x}$ each of the two school type dummy variables were added to each model. The loglikelihood ratio test statistic, computed as $-2 * \operatorname{loglikelihood}$ (null model) - (-2loglikelihood (fitted model)), was used to report whether differences between null and fitted models were statically significant. This statistic has a $\chi^{2}$ distribution with $q$ degrees of freedom where $\mathrm{q}$ is the difference in the number of parameters between the two models. The proportion of variance explained and effect sizes for all significant explanatory variables are also reported.

\section{Results}

\section{Validation of CSCEQ}

As indicated above, a principal components factor analysis with varimax rotation was performed on the data to substantiate the structure of the 7-scale 
CSCEQ. The 7 factor solution accounted for $41.3 \%$ of variance in scores. Each item had a factor loading of above 0.30 on their assigned scales and less that 0.30 on all other scales. These data attest to the sound structure of the CSCEQ.

Reliability coefficients (Cronbach coefficient $\alpha$ ) were computed for each scale (see Table 2). These results show that, apart from individualization, all scales had at least sound internal consistency. Indices ranged from 0.54 for individualization to 0.90 for interactions. These values compare favorably with those reported in previous learning environment research (see Fraser, 1998). Table 2 also shows means, standard deviations, minimum and maximum scores, and the standard error of measurement for each scale. The standard error of measurement statistics show that there is a $68 \%$ certainty that the true scale score of students would fall within approximately \pm 0.30 of their observed score on all scales.

Table 2 also reports the Kolmogorov-Smirnov $Z$ test for normality of scale score distributions. While all of these tests revealed statistically significant departure from normality, this is not a major concern to subsequent analyses as the sample size is quite large. Due to the Central Limit Theorem, non-normality has only a slight effect on the Type I error rates in tests of statistical inference (Stevens, 1999).

\section{Base Variance Components Models}

Before fitting conditional models in which student gender, grade, subject, and school type were modeled to explain each CSCEQ scale, it was essential to fit base variance components (i.e., null) models to the data for each CSCEQ scale. Table 3 shows the results of these analyses conducted with MLwiN. While it is expected that there would be appreciable amounts of variance within students, it is noteworthy that there were appreciable amounts of variance between class variance for all scales. These proportions, the intra class correlations for classes, ranged from $9.62 \%$ for cooperation to $23.81 \%$ for order and organization. In fact, all within student and between class variance components listed in Table 3 were statistically significant $(p<.05)$. The proportions of between schools variance, the intra class correlations for schools, for each scale were small and not statistically significant. As indicated earlier in this paper, -2loglikelihood statistics were computed for each model (see Table 3). These statistics, which are important for comparisons of fitted models with respective null models, ranged from 2,076.62 for individualization to $3,562.41$ for interactions. 
Table 3

Parameter Estimates and Variance Components for Null Model for 7 CSCEQ Scales

\begin{tabular}{|c|c|c|c|c|c|c|c|c|}
\hline \multirow{3}{*}{ CSCEQ Scale } & \multirow{3}{*}{$\begin{array}{c}\text { Fixed } \\
\text { School } \\
\text { Intercept }\end{array}$} & \multicolumn{6}{|c|}{ Random (Residual Variance) } & \multirow{3}{*}{-2loglikelihood } \\
\hline & & \multicolumn{2}{|c|}{$\begin{array}{l}\text { Between } \\
\text { Students }\end{array}$} & \multicolumn{2}{|c|}{$\begin{array}{c}\text { Between } \\
\text { Classes }\end{array}$} & \multicolumn{2}{|c|}{$\begin{array}{l}\text { Between } \\
\text { Schools }\end{array}$} & \\
\hline & & $\sigma^{2}$ & $\%$ & $\sigma^{2}$ & $\%$ & $\sigma^{2}$ & $\%$ & \\
\hline $\begin{array}{l}\text { Student } \\
\text { Affiliation }\end{array}$ & $3.52^{*}$ & $0.24^{*}$ & 84.72 & $0.03^{*}$ & 11.11 & 0.01 & 4.17 & $2,574.95$ \\
\hline Interactions & $3.71^{*}$ & $0.42^{*}$ & 74.61 & $0.11^{*}$ & 19.22 & 0.04 & 6.17 & $3,562.41$ \\
\hline Cooperation & $3.24^{*}$ & $0.25^{*}$ & 84.20 & $0.03^{*}$ & 9.62 & 0.02 & 6.18 & $2,580.47$ \\
\hline Task Orientation & $3.18^{*}$ & $0.33^{*}$ & 76.35 & $0.10^{*}$ & 23.65 & - & - & $3,113.58$ \\
\hline $\begin{array}{l}\text { Order \& } \\
\text { Organization }\end{array}$ & $2.72^{*}$ & $0.34^{*}$ & 70.19 & $0.12^{*}$ & 23.81 & 0.03 & 6.00 & $3,196.47$ \\
\hline Individualization & $2.67^{*}$ & $0.18^{*}$ & 79.65 & $0.04^{*}$ & 18.58 & 0.01 & 1.77 & $2,076.62$ \\
\hline Teacher Control & $3.46^{*}$ & $0.30^{*}$ & 78.16 & $0.08^{*}$ & 21.84 & - & - & $2,942.84$ \\
\hline
\end{tabular}

\section{Fitted Models}

To identify statistically significant explanatory variables of each standardized outcome variable, the five explanatory variables and the four interaction effect terms were added to each of the seven null (or base variance components) models. Backward elimination of variables that were not statistically significant at $p<.05$ was undertaken. Final model statistics are reported in Table 4 . It is noteworthy that there were no statistically significant interaction effects for any models and these terms were removed from all equations. Cooperation was explained by four variables: student gender, grade, subject, and school type (girls contrasted with coeducational). The most potent explanatory variable of cooperation was student gender with female students perceiving significantly higher levels of cooperation compared to male students $(\beta=0.22)$. Science classes had significantly lower cooperation compared to religious education classes $(\beta=-0.10)$. Task orientation and teacher control were explained by three variables. For task orientation, the explanatory variables were student gender $(\beta=0.12)$, grade $(\beta=-0.26)$, and subject $(\beta=0.23)$, and for teacher control, the variables were student gender $(\beta=0.11)$, grade $(\beta=-0.24)$, and school type: girls contrasted with coeducational $(\beta=-0.17)$. Student affiliation had two significant explanatory variables: student gender $(\beta=0.10)$, and grade $(\beta=0.16)$. Interactions and individualization had only one explanatory variable each: student gender $(\beta=0.17)$ and grade $(\beta=0.16)$, respectively. No equation with significant explanatory variables could be established for order and organization. 


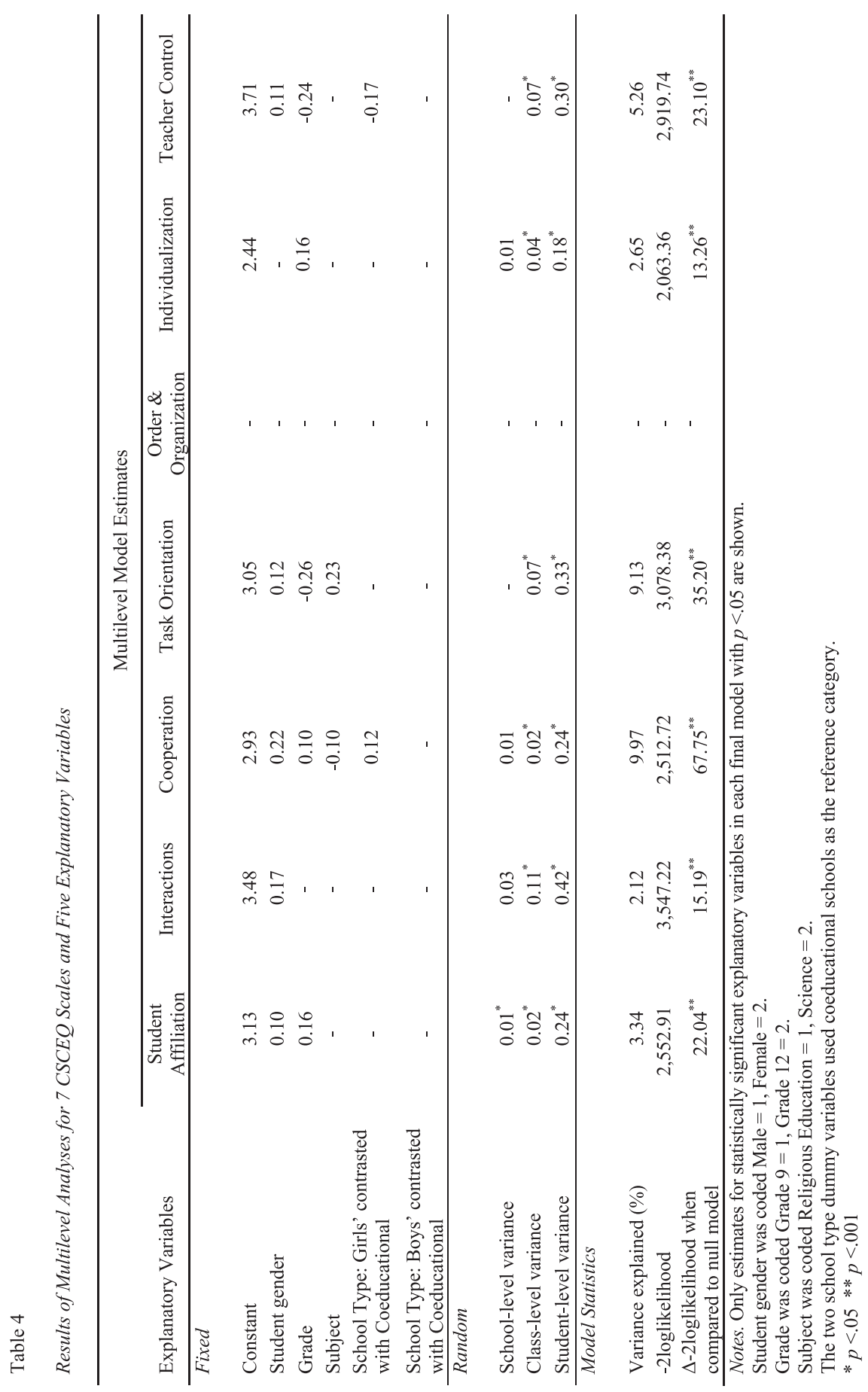


In summary, compared to male students, female students had significantly higher perceptions of student affiliation, interactions, cooperation, task orientation, and teacher control. Grade 12 students reported significantly higher student affiliation, cooperation, and individualization but lower task orientation and teacher control compared to Grade 9 students. Science students had significantly higher task orientation but lower cooperation than did religion students. With regard to the effect of school type, girls' schools had higher cooperation but lower teacher control compared to coeducational schools. There were no significant differences between CSCEQ scale scores for coeducational and boys' schools.

As indicated earlier in this paper, the loglikelihood ratio test statistic was used to report whether differences between null and fitted models were statistically significant. From Table 4, this statistic for student affiliation is 2,552.91. As there are two fitted variables in the final model and $\chi^{2}(2, N=$ $1,719)=13.82, p=.001$, there is a statistically significant difference between the null and fitted models recorded in the last row of Table 4. Similar results were found for the remaining 5 CSCEQ scales for which final models were fitted: interactions, $\chi^{2}(1, N=1,719)=10.83, p=.001$; cooperation, $\chi^{2}(4, N=$ $1,719)=18.47, p=.001$; task orientation, $\chi^{2}(3, N=1,719)=16.27, p=.001$; individualization, $\chi^{2}(1, N=1,719)=10.83, p=.001$; and teacher control, $\chi^{2}(3, N=1,719)=16.27, p=.001$.

Table 5 shows means for comparisons of subgroups. Effect sizes in terms of Cohen's (1988) $d$ (the difference between means scores divided by the pooled standard deviation) were computed for the 14 statistically significant comparisons. Values ranged from 0.07 for the effect of student gender on teacher control to 0.54 for the effect of student gender on task orientation $(M=0.31, S D=0.12)$. These effect sizes are small to moderate.

\section{Discussion}

Before discussing the substantive findings of this research, it is important to consider two methodological issues that are apparent from this study.

\section{Methodological Issues}

From a methodological perspective, few studies of classroom environment have embraced multilevel modeling of nested data. Data collected from students are often nested in classes and schools. It is not statistically sound to ignore class and school membership when analyzing such data (see den Brok, Brekelmans, \& Wubbels, 2006). It is also not sound to aggregate student scores to form class mean scores and use the class as the unit of analysis 


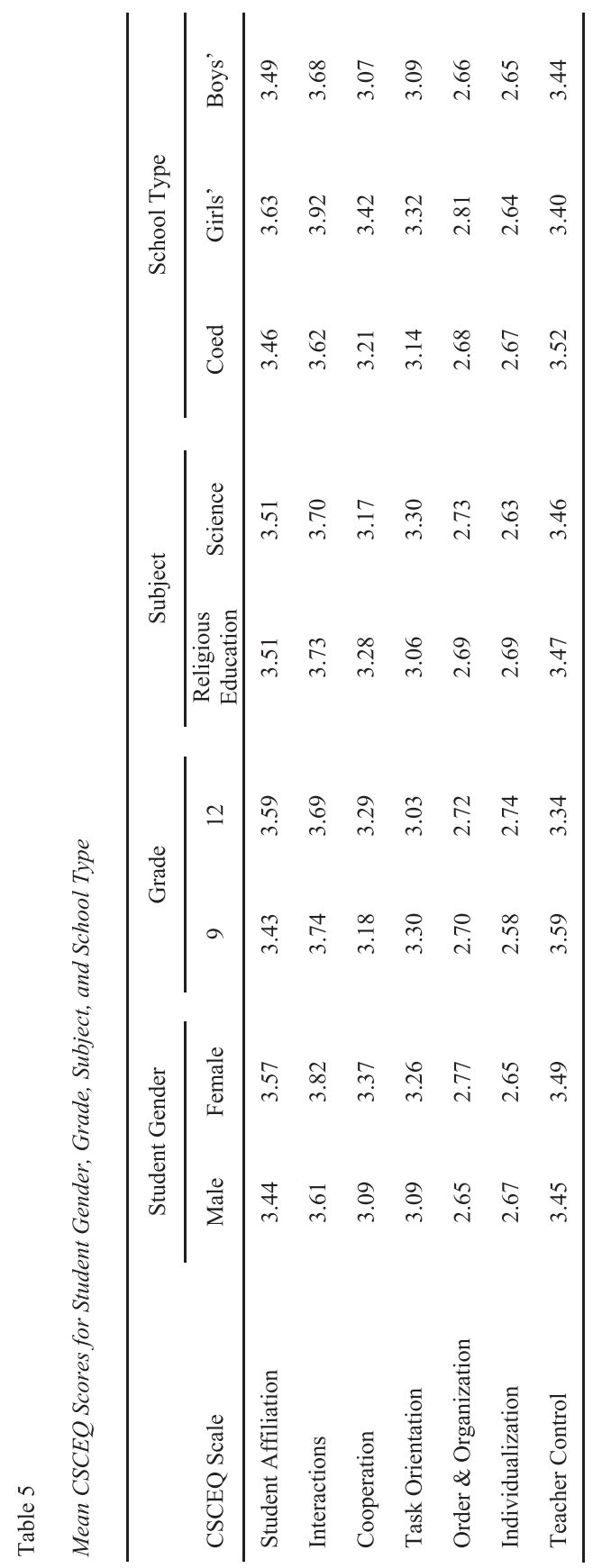


because of the potential for ecological fallacies - misinterpreting data by analyzing the data at one level but formulating conclusions at another level (see Alker, 1969). Multilevel analysis, which preserves the nested nature of the data, is required.

Additionally, the variance partitioning reported in the above section shows that statistically significant amounts of variance in all CSCEQ scale scores were evident between students and classes but not between schools. As between class variance ranged from $9.62 \%$ (cooperation) to $23.65 \%$ (task orientation), it can be asserted that the CSCEQ assesses constructs at the classroom level. Previous multilevel analyses conducted with classroom environment instruments have found similar proportions of variance at the class level. For example, Fisher, den Brok, and Rickards's (2006) study of the influence and proximity dimensions of the Questionnaire on Teacher Interaction (Wubbels \& Levy, 1993) extracted $28.3 \%$ and $30.1 \%$ of variance at the class level, respectively. Together with the CSCEQ's sound psychometric structure and construct validity, it can be concluded that the CSCEQ is a sound instrument to assess classroom environment as opposed to the idiosyncratic perceptions of individual students alone.

\section{Substantive Findings}

The above research findings reveal the influence of four determinants of classroom environments: student gender, grade, subject, and school type. As noted by Fraser (2002), classroom environment dimensions have been used as criterion or response variables in studies aimed at identifying how the classroom environment varies according to a range of determinants. In recent years, the most extensively researched determinant has been student gender. The present study found that student gender explained significant amounts of variance in student affiliation, interactions, cooperation, task orientation, and teacher control with female students reporting higher scores on these scales compared to male students. That is, female students perceived the classroom environment more positively than male students. Earlier high school classroom environment research on the effect of student gender by Lawrenz (1987) in Arizona, Wong and Fraser (1994) in Singapore, and Owens (1985) in Australia revealed similar findings to the present study. For example, Lawrenz used the Learning Environment Inventory (Fraser, Anderson, \& Walberg, 1982) to show that, compared to boys, girls perceived greater student cohesiveness, satisfaction, and difficulty but less friction in the classroom.

Several Asian studies, including those conducted by Fraser and Chionh (2000) in Singapore, Riah and Fraser (1998) in Brunei, and Kim, Fisher, and 
Fraser (2000) in Korea, have shown that female students perceive the classroom environment more positively than do male students. Other studies in Europe (e.g., Levy, den Brok, Wubbels, \& Brekelmans, 2003) and Australia (e.g., Rickards \& Fisher, 1997) confirm this view.

Overall, the present study's findings are consistent with all of this earlier research on the effect of student gender on classroom environment. The consistent and generalizable finding that females perceive the classroom environment more positively than do males raises a frame of reference issue: Compared to boys, do girls have a different frame of reference when assessing the classroom? Block (1994) used the psychological studies of Witkin to claim that females are more influenced by the surrounding field or context than males. That is, they exhibit greater sensitivity to the environment. Another interesting gender-related issue that warrants empirical investigation is the gender composition of coeducational classes and its influence on classroom environment.

In the present study, grade was a statistically significant positive determinant of student affiliation, cooperation, and individualization but a negative determinant of task orientation and teacher control. That is, compared to Grade 9 students, Grade 12 students perceived higher levels of student affiliation, cooperation, and individualization but lower levels of task orientation and teacher control. These results are generally consistent with three previous studies on the effect of grade on classroom environment (Randhawa \& Michayluk, 1975; Shaw \& Mackinnon, 1973; Welch, 1979). Randhawa and Michayluk's (1975) study reported a consistent pattern of reduced Grade 11 class scores compared to Grade 8 on dimensions of the Learning Environment Inventory (Fraser, Anderson, \& Walberg, 1982). Shaw and Mackinnon (1973) showed that as grade increased from Grade 9 to Grade 12, formality, favoritism, and goal direction decreased while democracy increased. Welch (1979) showed that, relative to high school students, junior high school students perceived their classes as having less satisfaction and democracy but more disorganization, formality, friction, cliqueness, and favoritism. Overall, these three previous studies showed that, as grade increased, cooperation increased but task orientation and teacher control decreased. The present study's results support these findings.

One criticism of this comparison of environments in Grades 9 and 12 classes is that the empirical results overestimate the differences between Grade 9 and Grade 12 because in Queensland, Grade 9 is compulsory and Grade 12 is post-compulsory. That is, students who might record negative perceptions of the environment drop out of school before Grade 12. This criticism is rejected for two reasons. First, the Grade 12 retention rate in 
Queensland Catholic schools is in excess of $90 \%$. Second, the school subjects involved in this study, religion and science in Grade 9 and religion and multistrand science in Grade 12, are taken by students of varying capabilities. All students in Catholic schools must take religion classes. Grade 9 science is part of the core curriculum and Grade 12 multi-strand science is not a highly academic subject. In fact, multi-strand science only exists because of the high retention rate. It has been added to the school curriculum to cater primarily to less academically capable students who previously would have left school at Grade 10.

The different perceptions that students hold at different stages of high schools brings into focus the issue of providing learning environments that meet the needs of adolescents at particular stages of maturity. The establishment of senior colleges for the post-compulsory grades of education (Grades 11 and 12 only) is one approach to providing quite different social structures for older students. Senior colleges usually have a separate campus from junior high schools so that different expectations of students can be established, a widened curriculum choice, an open campus model in which students come and go as they please, and staff who are sympathetic to a less traditional teaching role (Fraser, Williamson, \& Tobin, 1987). Research shows that senior colleges provide a better learning experience for young people by providing a change in teacher-student relationships through an environment of cooperation, independence, and self-responsibility (see Anderson, Saltet, \& Vervoorn, 1980; Polesel, 2002). Providing environments that match the needs of students at particular times in their adolescent development is not a new concept. It reflects the need-press theory introduced earlier in this paper. Environmental press is the external counterpart to the internal needs of the individual. In 1970, Stern developed a theory in which the degree of person-environment fit is related to student outcomes (see Fraser, 1986). From this theoretical perspective, it makes good sense to match the environment to student needs. Flexibility and responsiveness to these changing needs are important attributes of schools and classrooms in which students are highly engaged.

The present study revealed that, apart from higher levels of cooperation and lower levels of task orientation in religion classes, the environments in religious education and science classes were quite similar. Research on the effect of subject on the classroom environment has not been particularly prominent in recent times with the thrust of much contemporary research on links between classroom environment and outcomes. One exception to this trend was the work by Levy et al. (2003) who found that physics, science, 
and mathematics classes have less understanding and leadership compared to other subject areas.

The difference in task orientation for religion compared to science classes suggests that it is not as important to stay on the subject matter in religion classes compared to science classes. Furthermore, it is highly likely that this result is in some way connected to the view that religion (or religious education) is not considered to be very important by some students. Students are prone to assert that "RE doesn't count." In fact, research in Catholic schools by Flynn (1993) concluded that two-thirds of Grade 12 students in New South Wales do not take religion seriously. The reduced task orientation for religion reinforces the view that the formal curriculum is essentially assessment driven.

As reported above, differences between the classroom environments in coeducational, girls, and boys were generally small. The only statistically significant differences were between coeducational and girls' schools on two scales: cooperation and teacher control. No significant differences were recorded for the comparison of coeducational and boys' schools. The direction of the small differences in scores for coeducational and girls' schools are in general agreement with the findings of Trickett, Trickett, Castro, and Schaffner's (1982) study of single-sex and coeducational private schools in the United States discussed earlier in this article. By contrast, the results of Schneider and Coutts's (1982) study contrast with those of the present study. As noted earlier in this article, Schneider and Coutts found coeducational school students provided a considerably more favorable description of the social psychological environments of their schools than did the single-sex school students.

\section{Conclusion}

This article has reported classroom environment research conducted in 80 religious education and science classes in 20 Catholic schools in Australia. Four determinants (viz., student gender, grade, subject, and school type) were modeled as possible explanatory variables for each scale of the CSCEQ. While the above discussion has considered each of these determinants in its own right, it is worthwhile to consider the importance of classroom psychosocial environments to Catholic schools generally. Over 30 years ago, Flynn (1975) reflected on his first study on Australian Catholic schools by suggesting that there is a very close relationship between the social structure of the school-its climate and morale - and its effectiveness in developing the religious faith of its students. According to Flynn, the environment of the school is the Christian 
message to most students so that those who find school an alienating experience are also likely to reject its Christian message. The critical importance of the psychosocial environment to the very essence of the mission of the Catholic school must be acknowledged.

As noted earlier in this paper, there is a close link between classroom environment and student engagement. Recent research has identified the relationship between the teacher and student to be an important determinant of students' behavioral, emotional, and cognitive engagement in the classroom (Fredricks et al., 2004; Lee \& Burkam, 2003). While it is well established that student engagement can mediate the effects of school reforms on outcomes (see Guthrie \& Wigfield, 2000), it needs to be accepted that classroom environment has a potential mediating effect also. It is probable that the classroom environment mediates the effect of any reform on engagement and then on outcomes.

The research reported here is also important for two methodological reasons. First, the analyses reported in this article illustrate the effective use of multilevel analysis using MLwiN to partition variance and identify significant explanatory variables where data are nested. Potential directions for research in this area include studying the gender composition of coeducational classes and the charisms of particular religious orders in Catholic schools and the extent to which these characteristics might explain students' perceptions of the classroom environment. Cross-national research on classroom environment research in Catholic schools is also highly desirable so that the generalizability of results can be firmly established. Second, this study provides validation data for the CSCEQ and accordingly demonstrates its usefulness to Catholic school research and evaluation. The CSCEQ has been developed for Australian Catholic schools. However, it could be used as a starting point for psychosocial environment studies in schools with other religious and cultural traditions across the world. The research reported in this article demonstrates the importance of developing and validating context-specific learning environment instruments for research and evaluation in schools.

\section{References}

Abbott, W. M. (Ed.). (1966). The documents of Vatican II. London: Geoffrey Chapman.

Alker, H. R. (1969). A typology of ecological fallacies. In M. Dogan \& S. Rokkan (Eds.), Quantitative ecological analysis in the social sciences (pp. 69-86). London: MIT Press.

Allen, D., \& Fraser, B. J. (2007). Parent and student perceptions of classroom learning environment and its association with student outcomes. Learning Environments Research, 10(1), 67-82.

Anderson, G. J. (1971). Effects of course content and teacher sex on the social climate of learning. American Educational Research Journal, 8(4), 649-663.

Anderson, D., Saltet, M., \& Vervoorn, A. (1980). Schools to grow in: An evaluation of secondary colleges. Canberra, Australia: Australian National University Press. 
Australian Bureau of Statistics. (2008). Schools, Australia, 2007. Retrieved October 24, 2008, from http://www.abs.gov.au/AUSSTATS

Azimioara, M., \& Fraser, B. J. (2007, April). The effect of extended instructional time on learning environment, achievement, and attitudes in middle school algebra classes. Paper presented at the annual meeting of the American Educational Research Association, Chicago, IL.

Bathersby, J. (1992). The Catholic school: Creating the future together: Pastoral letter for Catholic education Sunday. Unpublished manuscript.

Block, J. H. (1994). Sex role identity and ego development. San Francisco: Jossey Bass.

Boy, A. V., \& Pine, G. J. (1988). Fostering psychosocial development in the classroom. Springfield, IL: Charles C. Thomas.

Bryk, A., Holland, P., Lee, V. E., \& Carriedo, R. A. (1984). Effective Catholic schools: An exploration. Washington, DC: National Center for Research in Total Catholic Education.

Cheng, S.-T. (1999). Perception of classroom environment in Hong Kong: Differences between students in junior and senior forms. Adolescence, 34(136), 793-798.

Cohen, J. (1988). Statistical power analysis for the behavioral sciences (2nd ed.). Hillsdale, NJ: Erlbaum.

Congregation for Catholic Education. (1977). The Catholic school. Strathfield, New South Wales, Australia: St Pauls.

Congregation for Catholic Education. (1988). The religious dimension of education in a Catholic school. Strathfield, New South Wales, Australia: St Pauls.

den Brok, P., Brekelmans, M., \& Wubbels, T. (2006). Multilevel issues in research using students' perceptions of learning environments: The case of the Questionnaire on Teacher Interaction. Learning Environments Research, 9(3), 199-213.

Dorman, J. P. (2002). Classroom environment research: Progress and possibilities. Queensland Journal of Educational Research, 18(2), 112-140.

Dorman, J. P., McRobbie, C. J., \& Foster, W. J. (2002). Associations between psychosocial environments in religious education classes and students' attitude toward Christianity. Religious Education, 97(1), 23-42.

Fisher, D. L., den Brok, P., \& Rickards, T. (2006). Factors influencing students' perceptions of their teachers' interpersonal behaviour: A multilevel analysis. In D. L. Fisher \& M. S. Khine (Eds.), Contemporary approaches to research on learning environments: Worldviews (pp. 51-74). Singapore: World Scientific.

Fisher, D. L., \& Khine, M. S. (Eds.). (2006). Contemporary approaches to research on learning environments: Worldviews. Singapore: World Scientific.

Flynn, M. (1975). Some Catholic schools in action: A sociological study of sixth form students in 21 Catholic boys' high schools. Sydney, New South Wales, Australia: Sydney Catholic Education Office.

Flynn, M. (1993). The culture of Catholic schools: A study of Catholic schools, 1972-1993. Homebush, New South Wales, Australia: St Pauls.

Fraser, B. J. (1986). Classroom environment. London: Croom Helm.

Fraser, B. J. (1998). Science learning environments: Assessments, effects and determinants. In B. J. Fraser \& K. G. Tobin (Eds.), International handbook of science education (pp. 527-564). Dordrecht, Netherlands: Kluwer.

Fraser, B. J. (2002). Learning environments research: Yesterday, today and tomorrow. In S. C. Goh \& M. S. Khine (Eds.), Studies in educational learning environments: An international perspective (pp. 1-25). Singapore: World Scientific.

Fraser, B. J. (2007). Classroom learning environments. In S. K. Abell \& N. G. Lederman (Eds.), Handbook of research on science education (pp. 103-124). Mahwah, NJ: Lawrence Erlbaum.

Fraser, B. J., Anderson, G. J., \& Walberg H. J. (1982). Assessment of learning environments: Manual for Learning Environment Inventory (LEI) and My Class Inventory (MCI) (3rd ed). Perth, Western Australia, Australia: Western Australian Institute of Technology.

Fraser, B. J., \& Chionh, Y. H. (2000, April). Classroom environment, self-esteem, achievement, and attitudes in geography and mathematics in Singapore. Paper presented at the annual meeting of the American Educational Research Association, New Orleans, LA. 
Fraser, B. J., Williamson, J. C., \& Tobin, K. G. (1987). Use of classroom and school climate scales in evaluating alternative high schools. Teaching and Teacher Education, 3(3), 219-231.

Fredricks, J. A., Blumenfeld, P. C., \& Paris, A. H. (2004). School engagement: Potential of the concept, state of the evidence. Review of Educational Research, 74(1), 59-109.

Geoghegan, P. B. (1860). Pastoral letter to the clergy and the laity of the diocese on the education of Catholic children. Adelaide, South Australia, Australia: G. Dehane.

Goh, S. C., \& Khine, M. S. (Eds.). (2002). Studies in educational learning environments: An international perspective. Singapore: World Scientific.

Guthrie, J. T., \& Wigfield, A. (2000). Engagement and motivation in reading. In M. K. Kamil, P. B. Mosenthal, P. D. Pearson, \& R. Barr (Eds.), Handbook of reading research (Vol. III, pp. 403-422). Mahwah, NJ: Lawrence Erlbaum.

Henderson, D. G., \& Fisher, D. L. (2008). Interpersonal behaviour and student outcomes in vocational education courses. Learning Environments Research, 11(1), 19-29.

Khine, M. S., \& Fisher, D. L. (Eds.). (2003). Technology-rich learning environments: A future perspective. Singapore: World Scientific.

Kim, H.-B., Fisher, D. L., \& Fraser, B. J. (2000). Classroom environment and teacher interpersonal behaviour in secondary school classes in Korea. Evaluation and Research in Education, 14(1), 3-22.

Koul, R., \& Fisher, D. L. (2006). A contemporary study of learning environments in Jammu, India. In D. L. Fisher \& M. S. Khine (Eds.), Contemporary approaches to research on learning environments: Worldviews (pp. 273-296). Singapore: World Scientific.

Lawrenz, F. P. (1976). Student perception of the classroom learning environment in biology, chemistry and physics courses. Journal of Research in Science Teaching, 13(4), 315-323.

Lawrenz, F. P. (1987). Gender effects for student perceptions of the classroom psychosocial environment. Journal of Research in Science Teaching, 24(8), 689-697.

Leavey, M. C. (1972). Religious education, school climate and achievement: A study of nine Catholic sixth-form girls' schools. Unpublished doctoral dissertation, Australian National University, Canberra, Australia.

Lee, V. E., \& Burkam, D. T. (2003). Dropping out of high school: The role of school organization and structure. American Educational Research Journal, 40(2), 353-393.

Levy, J., den Brok, P., Wubbels, T., \& Brekelmans, M. (2003). Students' perceptions of interpersonal aspects of the learning environment. Learning Environments Research, 6(1), 5-36.

Lewin, K. (1936). Principles of topological psychology. New York: McGraw-Hill.

Moos, R. H. (1979). Evaluating educational environments: Procedures, measures, findings and policy implications. San Francisco: Jossey Bass.

Moos, R. H., \& Trickett, E. J. (1987). Classroom environment scale manual (2nd ed.). Palo Alto, CA: Consulting Psychologists Press.

Mucherah, W. (2008). Classroom climate and students' goal structures in high-school biology classes in Kenya. Learning Environments Research, 11(1), 63-81.

Murray, H. A. (1938). Explorations in personality. New York: Oxford University Press.

Owens, L. (1985). The learning preferences of students and teachers: An Australian-American comparison. Teaching and Teacher Education, 1(3), 229-241.

Pace, C. R., \& Stern, G. G. (1958). An approach to the measurement of psychological characteristics of college environments. Journal of Educational Psychology, 49(5), 269-277.

Polesel, J. (2002). Schools for young adults: Senior colleges in Australia. Australian Journal of Education, 46(2), 205-221.

Randhawa, B. S., \& Michayluk, J. O. (1975). Learning environment in rural and urban classrooms. American Educational Research Journal, 12(3), 265-279.

Rasbash, J., Steele, F., Browne, W. J., \& Prosser, B. (2005). A user's guide to MLwiN Version 2.0. Bristol, United Kingdom: Centre for Multilevel Modelling, University of Bristol.

Riah, H., \& Fraser, B. J. (1998, April). Chemistry learning environments and its association with students' achievement in chemistry. Paper presented at the annual meeting of the American Educational Research Association, San Diego, CA. 
Rickards, T., \& Fisher, D. L. (1997, July). A report of research into student attitude and teacher student interpersonal behaviour in a large sample of Australian secondary mathematics classrooms. Paper presented at the annual meeting of the Mathematics Education Research Group of Australia, Rotorua, New Zealand.

Schneider, F. W., \& Coutts, L. M. (1982). The high school environment: A comparison of coeducational and single-sex schools. Journal of Educational Psychology, 74(6), 898-906.

Shaw, A. R., \& Mackinnon, P. (1973). Evaluation of the learning environment. Unpublished paper, Lord Elgin High School, Burlington, Ontario, Canada.

Steele, J. M., Walberg, H. J., \& House, E. R. (1974). Subject areas and cognitive press. Journal of Educational Psychology, 66(3), 363-366.

Stern, G. G. (1970). People in context: Measuring person-environment congruence in education and industry. New York: Wiley.

Stern, G. G., Stein, M. J., \& Bloom, B. S. (1956). Methods in personality assessment: Human behavior in complex social situations. Glencoe, IL: Free Press.

Stevens, J. P. (1999). Intermediate statistics: A modern approach (2nd ed.). Mahwah, NJ: Lawrence Erlbaum.

Trickett, E. J., Trickett, P. K., Castro, J. J., \& Schaffner, P. (1982). The independent school experience: Aspects of normative environments of single sex and coed secondary schools. Journal of Educational Psychology, 74(3), 374-381.

Walberg, H. J. (1976). Psychology of learning environments: Behavioral, structural, or perceptual? Review of Research in Education, 4, 142-178.

Walberg, H. J. (1991). Classroom psychological environment. In K. Marjoribanks (Ed.), The foundations of students'learning (pp. 255-263). New York: Pergamon Press.

Welch, W. W. (1979). Curricular and longitudinal effects on learning environments. In H. J. Walberg (Ed.), Educational environments and effects: Evaluation, policy and productivity (pp. 167-179). Berkeley, CA: McCutchan.

Welch, W. W., \& Walberg, H. J. (1972). A national experiment in curriculum evaluation. American Educational Research Journal, 9(3), 373-383.

Wong, A. F. L., \& Fraser, B. J. (1994, March). Science laboratory classroom environments in chemistry: A Singaporean perspective. Paper presented at the annual meeting of the National Association for Research in Science Teaching, Anaheim, CA.

Wubbels, T., \& Levy, J. (Eds.). (1993). Do you know what you look like? Interpersonal relationships in education. London: Falmer Press.

Jeffrey P. Dorman is an associate professor in the School of Education at Australian Catholic University. Correspondence concerning this article should be sent to Dr. Jeffrey P. Dorman, School of Education, Australian Catholic University, P.O. Box 456, Virginia, Queensland 4014, Australia. 